\title{
The Perception of the Langkawi Community on Solid Waste Management
}

\author{
NOOR KHAFAZILAH ABDULLAH*, ZAINI SAKAWI and LUKMAN ISMAIL \\ Centre for Social Studies, Development and Environment, \\ Faculty of Social Sciences and Humanities, National Universityof Malaysia.
}

http://dx.doi.org/10.12944/CWE.9.2.02

(Received: May 19, 2014; Accepted: July 03, 2014)

\begin{abstract}
The process of disposing solid wastes should be systematic and efficient. Various pollution may occur if solid wastes are not properly disposed. Pollution would not only affect the naturalenvironment but also exposed the community to various diseases. Therefore the community should be given exposure to practice efficient solid waste disposalfor their own benefits.Given the signficance of proper waste disposal issues for tourism locations, this study investigated the management of solid waste disposal at the renown Langkawi Island. The focus was on the understanding and awareness of the community of the locals, business people and tourists on the island. The findings indicated that thecommunity inPulau Langkawi was aware of the importance of efficient solid waste management. Yet, theirpractices differed in terms of propriety or impropriety of the method in the perspectives of solid waste management. These practices were found to be influenced by their level of knowledge on waste management issues and their educational background.
\end{abstract}

Key words: Pollution, Solid waste, Management of solid waste, Community of island

\section{INTRODUCTION}

Management of solid waste is currently a major challenge in many countries globally (Zafar, M. and Alappat, B.J. 2004; Emmanuel, N. et al. 2013;Joseph, K. et al. 2012). Urbanization, industrialization, housings and population growth are the factors contributing to the increase in generation of solid wastes (Abdul Manaf Bohari, 2006; Wee, S.T. 2006; Moh, Y.C. and Latifah Abd Manaf. 2014). Man various activities compelled increasing consumption of various finite sources ( $M d$. Abdul Jalil. 2010). The advancement of packaging technology altered the parameter for designing facilties for managing solid wastes. The increasing use of plactics and frozen foods reduce generation of household wastes, but inadvertently increased disposal of wastes at processing plants (Wee, S.T and Jamaluddin Md. Jahi. 2003). Due to increasing solid waste generation, environmental stakeholders should develop more disposal capacities as safer means for waste disposal (Martuzzi, M. et al. 2010).
Wee, S.T (2006) defined human produced waste as materials ceased to be useful and no longer needed in human activities. Efficient management of solid waste is vital to reduce demand for natural resources and reduction of pollution. The efficiency willalso save human labour, enhance management system, produce energy, reduce demand for landfills and create job opportunities.

Authorities in developing countries in particular tend to overlook the significance of waste minimization strategies, leading to situations where all "wastes" are sent to dumpsites for final disposal. This has made many cities lose sight of the economic value of waste and make them potential candidates for poor solid waste management (Oteng, M. and Ababio. 2011). Thus, Malaysian government have implemented various policies to enhance the efficiency of solidwaste management and prevent undesirable impact on human and the enviroment of Malaysian islands, given their rich biodvesity that should be sustained and prevented from 
degeneration.Significance of waste management for islands environment have attracted various studies from environment scientists.

Tan, R.B.H dan Khoo, H.H. (2006) studied methods for solid waste management in Singapore. They discovered that incinerator posed harm to human health and environment. Eventhough energy is produced from the incinerator operation, yet it also caused pollution (heavy metals and dioxides). An ealier study on Langkawi island was by Johan Afendi Ibrahim dan Mohamad Zaki Ahmad (2007) who studied the effects of the Geopark on tourism and solid wastes in Langkawi.

Unmanaged or poorly managed solid wastes disposal created dirty landscape and odourous air both ruinous to natural environment. The situation also brought diseases to human. Collaboration between environmental authorities and health professionals are vital to educate the community with innovative and practical information on managing solid waste disposal(Sessa, A. et al. 2009).

Efficient solid waste management could be implemented if the authorities collaborate with the local community. To investigate the collaboration scenario in Langkawi, this study therefore aimed to find out the perception of the community at the Langkawi island on the solid wastes management and disposal on their island.

\section{Method and area of study}

Questionnaires were used to gather data for this study. A total of 30 questionnaires were distributed a purposive samplingof respondents, consisting of the locals, business people and tourists on the Langkawi island. Langkawi island is located about $30 \mathrm{~km}$ offshore from the west coast of Peninsular Malaysia. The size of langkawi, the major island is 32,000 hectares, and the total for all the islets combined is 47,848 hectares. The average temperature is $33^{\circ} \mathrm{C}\left(33-34^{\circ} \mathrm{C}\right)$ and annual rainfall is at $2500 \mathrm{~mm}$. The areas involved in the study were Kampung Kilim, Kampung Sungai Itau, Kampung Titi Batu Dame Air, Kampung Matsirat, Kampung Belanga Pecah, Kampung Kisap, and Taman Mulia.

\section{RESULTS}

\section{Background of the respondents}

The respondents were Malays $(60.6 \%)$, Chinese (6\%) and Indian (4\%). Three respondent categories were locals, business people and tourists. Locals made up the most number of respondents at $42.4 \%$, followed by business people $30.3 \%$ and tourists at $18.2 \%$.The respondentscategories are for obtainingvaried perception based on their varied personal backgrounds.

Several major areas were identified to obtain the factual information from local respondents on the knowledge of solid waste management issues. Kampung Maksirat respondents were the most at $24.2 \%$ (8 persons),followed by those from Kampung Kilim and Taman Mulia both at $18.2 \%$ respectively. Respondents from Kampung Sg. Itau, Kampung Kisap were at $9.1 \%$ (3 persons). Respondents from Kampung Titi Batu Dame Air and Kampung Belanga Pecah were both at $3 \%$ each ( 1 respondent) (Figure 1). More than half of the respondents' households consisted of 3 to 5 people $(60.6 \%)$ compared to those with 1 to 3 members at $30 \%$.

The respondents' educational level shows that $42.2 \%$ were SPM and STPM qualified (14 respondents). About $30.03 \%$ (10 respondents) had no schooling. Nevertheless, about $9.1 \%$ managed to obtain diploma and university education.Figure 2 shows the number of respondents receiving special training or eduation on management of solid wastes. Regarding exposure to specific education or training on environmental issues, the positive and negative responses were an rather even. About $30 \%$ (10 persons) indicated that they obtained the educational exposure on the environmental issues. Yet, same percentage (30\%) of respondents indicated otherwise. About $45.4 \%$ of respondents never received any special educational exposure on the subject. While $27.3 \%$ ( 9 persons) uncertain. Only $18.2 \%$ (6 respondents) received the educational experience.

\section{Knowledge on management of solid wastes}

Fifteen respondents $(45.5 \%)$ indicated that the solid waste management system shoud be systematic, while $45.5 \%$ more (15 persons) noted that efficiency means consistency in solid waste 
collection. The MPL was deemed wholly responsible for the solid waste management and disposal. Regarding respondeents' method of waste disposal (Figure 3), 36.4\% of the respondents committed open burning, $30.3 \%$ (10 persons)did burnand bury. Other $24.2 \%$ (8 persons) recycled their solid waste. Yet, incinerators was left out. The respondents did not have much information of the incinerator function in solid waste management and disposal.

About $30.3 \%$ or 10 respondent opined that solid waste disposal is a major issue in Malaysia (Figure 4). About 24.2\% respondents regarded toxic waste as major issue, and $18.2 \%$ (6 persons) thought it is the industrial waste. About $12.1 \%$ (4 persons) viewed clinical waste as a major problem, followed by gaseous waste at $6.1 \%$ (2 persons).

Other than those, $51.5 \%$ or (10 respondents) noted that inefficient waste management and disposal was a major issue in Malaysia. Thirteen respondents $(39.4 \%)$ regarded landfills as a major issue affecting efficiency of solid waste management.
Respondents' view on management of solid waste in Langakawi island

Some respondents indicated their uncetainty if solid wastes have been the cause of the pollution in Langkawi waters. Many respondents disagreedthat hotels activities and business at Pekan Kuah were the main factors to the pollution. Other factors contributing to the pollution were identified as the indutries and maritime activities. Many respondents also agreed that waste could be a source of income through recycling activities.

Almost all respondents agreed that the wastes were harmful to human. About 54.5\% (18 persons) opined that inefficient management caused skin diseases. While, 36.4\% (12 persons) said it caused cancer. Evidently, the level of respondents awareness of health implication was rather high. Most respondents disposed almost $3 \mathrm{~kg}$ of wastes per day, consisting of food leftovers at 54.5\% (18 persons); disposed plastics $36.4 \%$. About $60.6 \%$ (20 persons) disposed twigs and branches collected in the waters. About $15.2 \%$ (5 persons) collected and disposed drink cans from the shores.

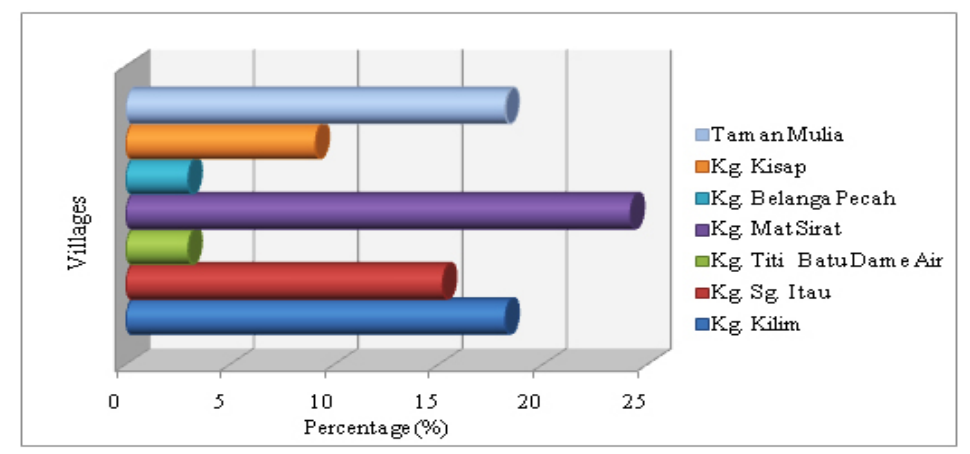

Fig.1: Number of Respondents Per Area of Study

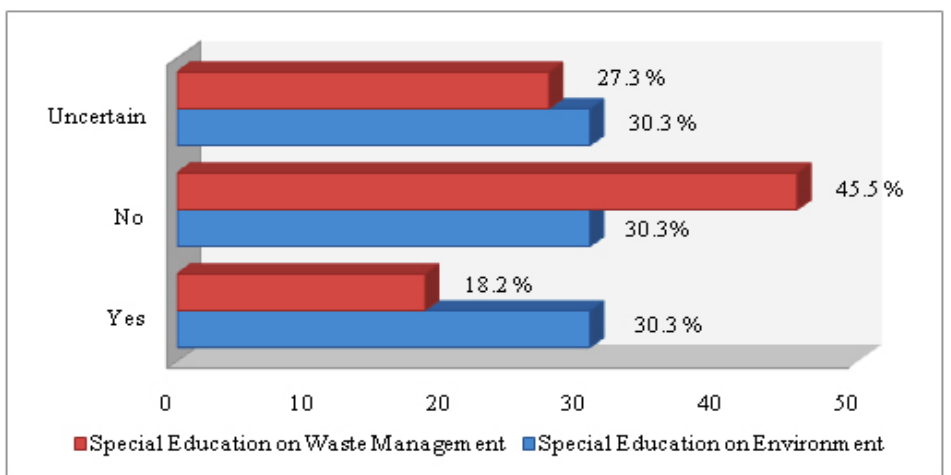

Fig. 2: Special Environemtal Education and Waste Management Among Community 
Figure 5 shows the respondents' knowledge on the techniques of waste disppsal. About $30.3 \%$ (10 persons) understood reduction of sources and recycling. Those who were aware of the landfills were

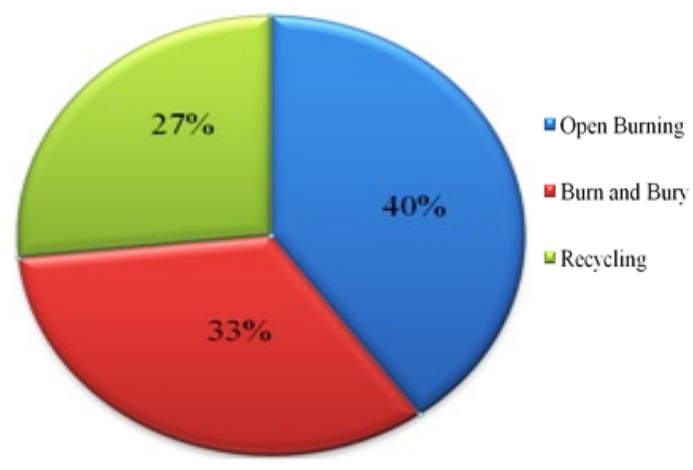

Fig.3: Method of Respondents‘ Waste Disposal at $15.2 \%$ (5 persons), while $9.1 \%$ (3 persons) knew compositing, and $6.1 \%$ of the incinerator.

Public health, air pollution, odour disturbance, hazardous gas emissions are among the common phenomena occurring if improperly managed of solid wastes was practice (Zamali Tarmudi et al. 2009). Figure 6 shows that $27.3 \%$ (9 persons) stated that water pollution could occur due to poorly managed waste disposal. About $21.2 \%$ (7 persons) opined that solid wastes could cause airpollution, And 18.2\% (6 persons) noted that solid waste caused odour pollution. About $12.1 \%$ or 4 respondents agreed that solid waste dumped into drainage could cause sewerage clogging. While $6.1 \%$ (2 persons) regarded solid wasste as All respondents agreed that more tourists would flock to Langkawi if it is free from solid waste issues. About $60.6 \%$ (20 persons) indicated that they would

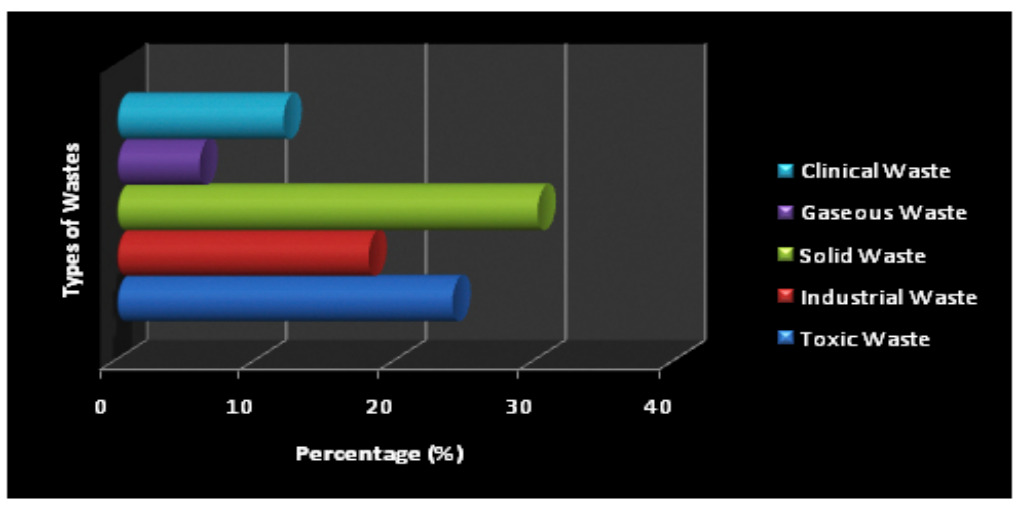

Fig.4: Major management issues per types of wastes

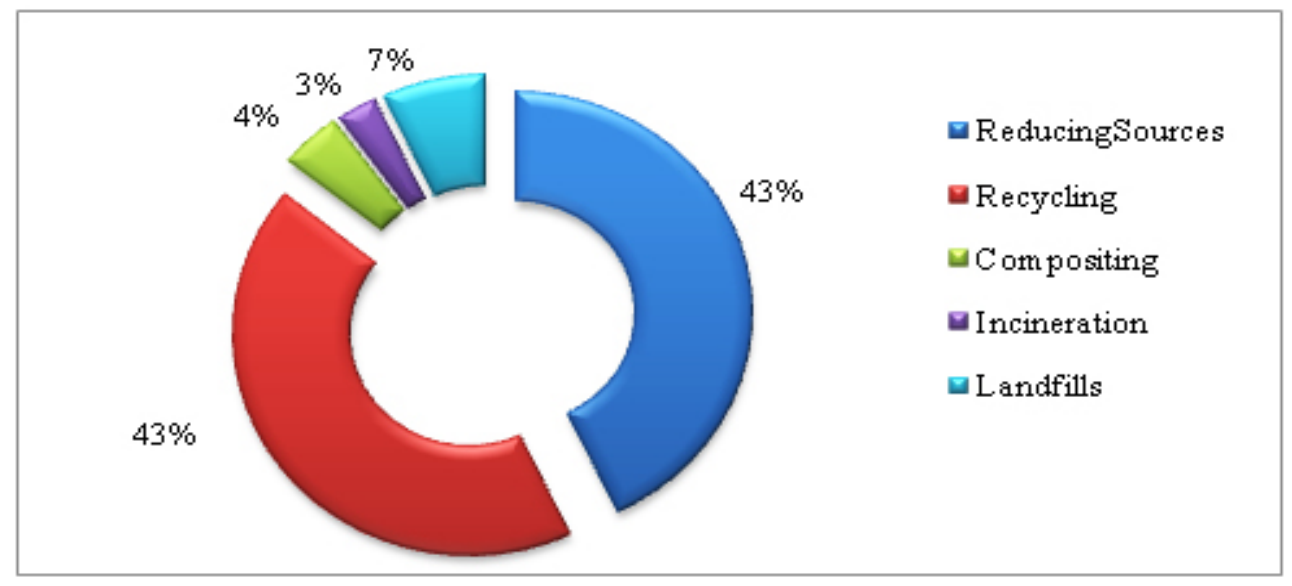

Fig. 5: Respondents‘ Knowledge on Techniques of Waste Disposal 


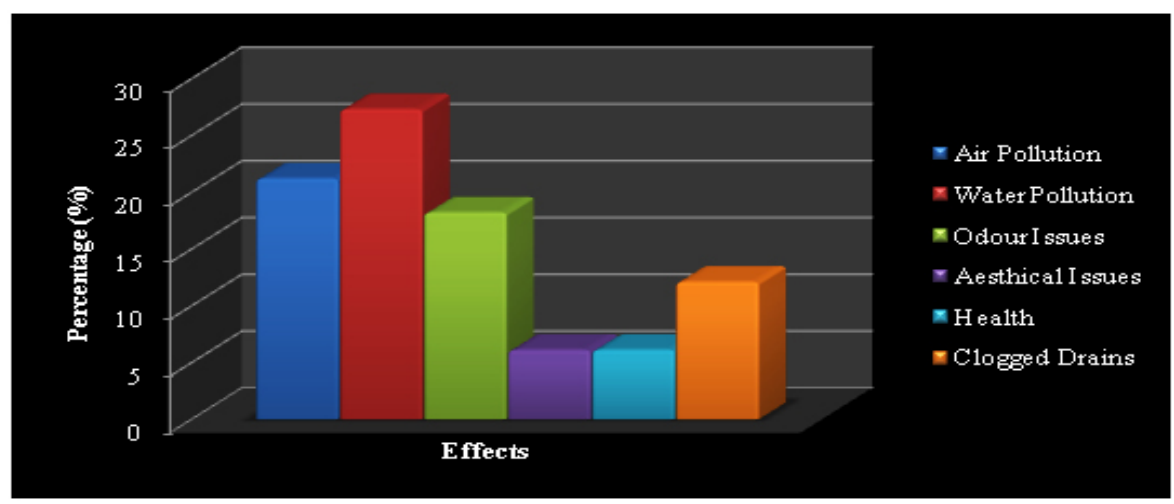

Fig.6: Enviromental Effects Due to Poor Management of Solid Wastes.

disposed their solid wastes at proper places, while $30.3 \%$ (10 persons) would pt to reduce usage of sources to contribute towards resolving or mitigating Langkawi solid waste management issues.

\section{DISCUSSION}

Efficient solid waste management and disposal are vital to sustain the rich biodiversity of the island. This study clearly indicated that the community realised the importance of managing efficientsolid waste managent to sustain their wellbeing and conserve Langkawi environment and biodiversity. Yet their various educational backround influenced their way of disposing their own solid waste; which were a mix of proper and improper method with implications on both their well-being and environment. The respondents tend to opt for open burning, dumping at sea and some uncontrolled method to dispose the solid waste. If these attitude and behaviour were not corrected, more serious impact will appear in the near future.

Teachers at school play a significant part in determining the successful implementation of environmental education among the young. It was demonstrated that teacher's attitude, knowledge and behaviour towards the environment affect and influence the students' attitude (Summers, M. 2000).The study about level of knowledge, environmental concern and ecologically conscious consumer behaviours and identify the extent of involvement in nature-related activities of school teachers in Selangor, Malaysia was conducted by Aini Mat Said et al. 2008. The study found that the environmental knowledge was fair but generally poor in understanding of the underlying causes of environmental problems. The practices of environmentally showroom behaviours were not in concert with the level of concern and knowledge. The respondents were not actively involved in naturerelated activities.

Nevertheless, it is perceived, the community involved in this study were aware of the importance of efficient solid waste management. Generationand management of solid waste involved various strategies such as recycling, reuse, collection, financial capacity, involvement of the authorities, and the public and private sectors. The attitude towards recycling is significantly influenced by perceived value, awareness and actual gains perceived by the consumers. Recycling behaviour was significantly influenced by resistance to change and attitude towards recycling (Ramayah, T. and Rahbar, E. 2013; Hope, E.T and Kingston. 1998; Wan, C. 2012). Plastics are probably the most common recyclable materials with high potential for recycling in Malaysia (Moh, Y.C. and Latifah Abd Manaf. 2014).Educational and promotional programmes highlighting the benefits and importance of recycling activities and convenience of the recycling facilities can be adopted as the key strategies to encourage recycling (Wan, C. et al. 2012). Recycling could reduce the burden of prosessing disposed wastes (Chiemchaisri, C. et al. 2007) and supports the economy as recycling provides wide profitable business ventures opportunities (Moh, Y.C and Latifah Abd Manaf. 2014) 
The community was also aware of the responsibility of the MPL on solid waste management and disposal. Yet, they tend to over relied on the MPL to manage the disposal. This posed an issue to the MPL, for the initial stage of proper collection and binning of the waste prior to MPL collection was not well-practiced by the community themselves. The MPL on its part has been holding community activities like collaborative cleaning campaigns to raise awareness of the community on solid waste management. This is a good practice for good solid waste management begins at home (Aung, M.and Arias, M.L. 2006).

Government should necessarily take steps to educate the citizenry on waste reduction and separation as a matter of national policy. Probably, the government will have to enact the appropriate waste minimization legislation as a first step (Oteng, M. and Ababio. 2011). Sharing new information about activities by authorities to community probably will have some positive implications on solid waste management practices (Asmawati Desa et al. 2012). Thus the MPL also should properly informthe community of the services and exact locations of waste disposal facilities. This shall compel the community to practice proper disposal of their wastes. Despite their awareness of an incinerator facility, not many respondents knew of its real function. This happened due to lack of information and exposure on the function of the incinerator to the community. Other than that, the JAS had not been quite active in conducting exposures and educating the public on proper method for waste disposal in Langkawi. Ignorance of these issues will cause the community great losses and open burning may continue to be practiced in time to come.

\section{CONCLUSION}

Generally the community at the Langkawi areas of study understood and aware ofthe issues on solid waste management. Nevertheless, their method of disposing the solid wastes varied according to the level of education. Respondents without proper knowledge on solid waste management and disposal tend to indiscriminately dispose their wastes such as through open burning.Therefore, the stakeholders such as the MPL(Langkawi Town Council) and JAS (Department of Environment) should be more proactive to handle the issues and monitor the development on the ground throughout Langkawi. More community activities such as environment cleaning programmes should be held to enhance their awareness and love for sustainable environment. Campaigns shouldalso be held at schools and higher learning institutions to inculcate positve attitude and actions towards maitaining and sustaining healthy Langkawi enviroment and biodiversity.

\section{REFERENCE}

1. Abdul Manaf Bohari, Tanggungjawab Social Korporat Terhadap Alam Sekitar Di Malaysia: Kepentingan pelaksanaan, Sintok, Universiti Utara Malaysia(2006).

2. Aini Mat Said, Fakhrul-Razi Ahmadun, Laili Hj. Paim and Jariah Masud, International Journal of Sustainability in Higher Education, 4, 305 (2003).

3. Asmawati Desa, Nor Ba'yah Abd Kadir and Fatimah Yusooff, Environmental Awareness and Education: A Key Approach to Solid Waste Management (SWM), Malaysia, 101 (2012).

4. Aung, M. and Arias, M.L., Management of Environmental Quality: An International
Journal, 17: 740 (2006).

5. Chiemchaisri, C., Juanga, J.P. and Visvanathan, C., Municipal solid waste management in Thailand and disposal emission inventory Environ Monit Assess, 135: 13 (2007).

6. Emmanuel, N., Emile, T., Benoit, M. and Pierre, E.S., The Open Waste Management Journal, 6: 5 (2013).

7. Hobe, E.T and Kingston, Solid Waste Management: Critical Issues for Developing Countries, Jamaica: Canoe Press, University of the West Indies, 289 (1998).

8. Johan Afendi Ibrahim dan Mohamad Zaki Ahmad, Sintok: Universiti Utara Malaysia (2007). 
9. Joseph, K., Rajendiran, S., Senthilnathan, R. and Rakesh, M., Journal of Mater Cycles Waste Management, 14: 75 (2012).

10. Martuzzi, M., Mitis, F., and Forastiere, F., European Journal of Public Health, 20: 21 (2010).

11. Md. Abdul Jalil, Journal of Suistainable Development, 3: 91 (2010).

12. Moh, Y.C. and Latifah Abd Manaf, Resources, Conservation and Recycling, 82: 50 (2014).

13. Oteng, M. and Ababio, Geo Journal, 76: 551(2011).

14. Ramayah, T. and Rahbar, E., Management of Environmental Quality: An International Journal, 24: 782 (2013).

15. Sessa, A., Giuseppe, G. D, Marinelli, P. and Angelillo, I.F., European Journal of Public Health, 20: 631(2009).

16. Summers, M., Environmental Education
Research, 31: 12 (2000).

17. Tan, R.B.H and Khoo, H.H., Journal of the Air and Waste Management Association, 244 (2006).

18. Wan, C., Cheung, R. and Shen, G.Q., Recycling attitude and behaviour in university campus: a case study in Hong Kong. Facilities, 30: 630 (2012).

19. Wee, S.T., Sintok: Universiti Kebangsaan Malaysia (2006).

20. Wee, S.T. and Jamaluddin Md Jahi, Bangi: Universiti Kebangsaan Malaysia (2003).

21. Zafar, M. and Alappat, B.J., Management of Environmenat Quality: An International Journal (2004).

22. Zamali Tarmudi, Mohd Lazim Abdullah and Abu Osman Md Tap, Journal of Technology, $51: 1(2009)$. 